Tarbawi: Jurnal Ilmu Pendidikan p-ISSN:1858-1080 | e-ISSN: 2615-6547

Vol. 16, No. 1, Juli 2020, 11 - 21

\title{
Implementasi Program Gerakan Literasi Sekolah di Sekolah Menengah Pertama (SMP)
}

\author{
Antoni Widodo \\ Universitas Negeri Jakarta \\ E-mail: antoniwidodo3@gmail.com
}

\begin{abstract}
Abstrak. Artikel ini bertujuan untuk mengetahui implementasi program Gerakan Literasi Sekolah (GLS) di SMP IT Insan Harapan Kota Tangerang Selatan. Jenis penelitian ini menggunakan kualitatif deskriptif. Informan penelitian meliputi Kepala Sekolah, Wakil Kepala Sekolah Bidang Kurikulum, Guru, dan Peserta didik. Metode pengumpulan data menggunakan wawancara, observasi, dan dokumentasi. Hasil penelitian menunjukan bahwa Gerakan Literasi Sekolah belum dilakukan dengan rutin. Upaya yang dilakukan oleh sekolah dalam mendukung Gerakan Literasi 1) Menyediakan buku bacaan yang beragam 2) Membuat kegiatan 2 jam membaca di hari jumat 3) melaksanakan 15 menit membaca sebelum pembelajaran di mulai 4)membuat laboratorium komputer (warnet sekolah). Sedangkan kendala yang dihadapi dalam melaksanakan program Gerakan Literasi Sekolah (GLS) 1) tidak konsisten dalam penerapan 15 menit membaca sebelum pembelajaran di mulai 2) pelaksanaan yang tidak rutin dalam menerapkan kegiatan membaca 2 jam pembelajaran setiap minggu 3) masih kurangnya sarana dan prasana perpustakaan 4) kurangnya pengawasan dalam implementasi Gerakan Literasi Sekolah (GLS), implementasi program Gerakan Literasi Sekolah perlu adanya dukungan dari komponen sekolah seperti pengawas, Kepala Sekolah, dan Komite Sekolah.
\end{abstract}

Kata kunci: Implementasi Gerakan Literasi Sekolah, Sekolah Menengah Pertama

\begin{abstract}
This article aims to find out the implementation of the School Literacy Movement program at SMP IT Insan Harapan, South Tangerang City. This type of research uses descriptive qualitative. Research informants included the Principal, Deputy Principal for Curriculum, Teachers, and Students. Data collection methods using interviews, observation, and documentation. The results showed that the School Literacy Movement had not been carried out routinely. Efforts made by schools in supporting the Literacy Movement 1) providing diverse reading books 2) Making 2 hours of reading activities on Friday 3) carrying out 15 minutes of reading before learning starts 4) creating a computer laboratory (school cafe). While the obstacles encountered in implementing the School Literacy Movement (GLS) program 1) are inconsistent in the application of 15 minutes of reading before learning begins 2) non-routine implementation of implementing reading activities 2 bours of learning every week 3) the lack of library facilities and infrastructure 4 ) lack of supervision in the implementation of the school literacy movement (GLS), the implementation of the school literacy movement program needs the support of school components such as supervisors, principals, and school committees.
\end{abstract}

Keywords: Implementation of the School Literacy Movement, Middle School 


\section{PENDAHULUAN}

Undang-undang Nomor 20 Tahun 2003 tentang sistem Pendidikan Nasional menyebutkan, bahwa Pendidikan nasional berfungsi mengembangkan kemampuan dan membentuk watak serta peradaban bangsa yang bermartabat dalam rangka mencerdaskan kehidupan bangsa (Trianto, 2017). Amanat undang-undang ini berarti tugas dari adanya Pendidikan membentuk karakter bagi para penerus bangsa agar memiliki sumber daya manusia yang sesuai dengan karakter bangsa.

Untuk mewujudkan peserta didik yang unggul budi pekertinya pemerintah membuat peraturan melalui Permendikbud Nomor 23 Tahun 2015 tentang Penumbuhan Budi Pekerti dengan membuat Gerakan Literasi Nasional. Ranah dari Gerakan Literasi Nasional meliputi Gerakan Literasi Sekolah, Gerakan Literasi Masyarakat, dan Gerakan Literasi Keluarga. Pengembangan ini juga diperkuat dengan adanya peraturan Presiden Republik Indonesia Nomor 87 tahun 2017 tentang Penguatan Pendidikan Karakter (PPK), pendidikan karakter yang didefinisikan menurut Kasmawati \& Zaenudin sebagai pendidikan nilai, pendidikan pengaturan, pendidikan moral dan pendidikan disposisi untuk mengembangkan kemampuan siswa dalam membuat keputusan, peduli terhadap masyarakat dan berbuat kebaikan (Abbas \& Bin Hassan, 2014). Pendidikan karakter ini berdasarkan peraturan Presiden tersebut didalamnya terdapat 17 aspek yang dianggap dapat mewujudkan bangsa yang berbudaya, meiliputi nilai-nilai religius, jujur, toleran, disiplin, bekerja keras, kreatif, mandiri, demokratis, rasa ingin tahu, semangat kebangsaan, cinta tanah air, menghargai prestasi, komunikatif, cinta damai, gemar membaca, peduli lingkungan, peduli sosial, dan bertanggung jawab dari aspek ini diharapkan dapat terinternalisasikan melalui program Gerakan Literasi Nasional (GLN).

Program Gerakan Literasi Nasional dibuat karena adanya masalah-masalah terkait dengan kemampuan literasi siswa seperti data Hasil survei yang dilakukan Programme for International Student Assessment (PISA) mulai dari tahun 2009 rangking siswa Indonesia menunjukan 57 dengan skor 396 dimana rata-rata skor dari negara yang berpartisipasi adalah 493, tiga tahun kemudian yaitu tahun 2012 rangking siswa Indonesia turun menjadi 64 dengan perolehan skor 396 sedangkan nilai ratarata 496 dengan total negara yang berpartisipasi patahun tahun 2009 dan 2012 adalah 65 negara. pada tahun 2015 terhadap 72 negara didunia dalam bidang science, reading, mathematics menunjukan hasil skor untuk Indonesia secara berturut-turut yaitu 403, 397, 386 (Vanbela, Fuad, \& Marini, 2018).

Dengan adanya data dari penelitian PISA tersebut pemerintah ingin meniningkatkan kualitas Pendidikan dengan mengubah kurikulum nasional dan membuat program-program yang dapat mendongkrak kemampuan 6 dasar dimensi literasi yaitu baca tulis, numerasi, sains, digital, finansial, serta budaya dan kewargaan yang dikembangkan melalui program Gerakan Literasi Sekolah (GLS) 
(Kemendikbud, 2017). literasi yang diartikan sebagai kemampuan kemampuan memahami, mengelola, dan menggunakan informasi dalam berbagai konteks (Hartati, 2017). Ini dimaksudkan pemerintah melalui kemendikbud dapat meningkatkan daya nalar siswa khususnya dalam level memahami sampai dengan mengkreasikan sehingga kemampuan peserta didik akan terdongkrak dalam memecahkan soal yang berlevel High Order Thingking Skills (HOTS) dengan assesment standard PISA.

Selain tujuan dari literasi adalah siswa berpikir tingkat tinggi menurut Suragangga tujuan dari adanya Gerakan Literasi Sekolah (GLS) yaitu 1) menumbuhkembangkan budaya literasi membaca dan menulis siswa di sekolah, 2) meningkatkan kapasitas warga dan lingkungan sekolah agar sadar akan pentingnya budaya literasi, 3) menjadikan sekolah sebagai taman belajar yang menyenangkan dan ramah anak, dan 4 )menghadirkan beragam buku bacaan dan mewadahi berbagai strategi membaca untuk mendukung keberlanjutan pembelajaran (Tarmidzi \& Astuti, 2020)

Adapun tahapan pelaksanaan gerakan literasi sekolah dibagi ke dalam tiga tahapan, yaitu sebagai berikut(Antasari, 2017):

1. Tahap pembiasaan

Pada tahapan ini, sekolah menyediakan berbagai buku dan bahan bacaan yang dapat menarik minat peserta didik dan melaksanakan kegiatan yang meningkatkan minat baca peserta didik. Misalnya, menata sarana dan area baca, menciptakan lingkungan yang kaya teks, mendisiplinkan kegiatan membaca 15 menit sebelum pelajaran dimulai, melibatkan publik dalam Gerakan Literasi Sekolah (GLS).

2. Tahap pengembangan

Setelah kebiasaan membaca terbentu pada warga sekolah, maka sekolah dapat masuk ke tahap pengembangan yang bertujuan untuk mengembangkan kecakapan literasi peserta didik melalui berbagai kegiatan literasi.

Misalnya, kegiatan membaca cerita dengan intonasi, mendiskusikan suatu bahan bacaan, menulis cerita, dan melaksanakan kegiatan festival literasi

\section{Tahap pembelajaran}

Pada tahapan ini, sekolah menyelenggarakan berbagai kegiatan yang bertujuan untuk mempertahankan minat baca dan meningkatkan kecakapan literasi peserta didik melalui buku-buku pengayaan dan buku teks pelajaran. Misalnya, kegiatan pembinaan kemampuan membaca, menulis cerita, dan mengintegrasikan kegiatan literasi dalam tahapan pembelajaran.

Implementasi Gerakan Literasi Sekolah setiap sekolah memiliki program yang berbeda-beda namun tujuanya sama yaitu menginginkan penumbuhan budi perkerti, namun apakah implementasi dari program ini apakah sudah terlaksana dengan baik? Hal ini yang perlu diketahui dan upaya 
perbaikan melalui evaluasi juga dibutuhkan demi suksesnya program GLS yang sudah diprogramkan.

\section{METODE}

Menurut Arikunto Penelitian ini merupakan penelitian kualitatif deskriptif penelitian deskriptif merupakan penelitian yang dimaksudkan untuk mengumpulkan informasi mengenai status atau gejala yang ada, yaitu gejala menurut apa adanya pada saat penelitian dilakukan, Pendekatannya deskriptif dilakukan untuk mengumpulkan informasi mengenai status suatu gejala yang lakukan, tidak dimaksudkan untuk mengukur hipotesis tertentu, tetapi hanya menggambarkan apa adanya tentang variabel, gejala, dan keadaan (Irkhamiyati, 2017). sehingga diperoleh gambaran mengenai pelaksanaan program gerakan literasi sekolah di SMP IT Insan Harapan.

Data penelitian terdiri dari data primer dan data sekunder. Data primer atau langsung didapatkan melalui 1) informasi yang diperoleh dari hasil wawancara dengan kepala sekolah, wakil kepala sekolah bidang kurikulum, guru, dan siswa, dan 2 ) hasil pengamatan di lapangan terkait dengan fisik, dokumen, dan keadaan yang berkaitan dengan implementasi Gerakan literasi sekolah. Sedangkan data sekunder penelitian ini adalah data-data sekunder yang dapat digunakan untuk melengkapi hasil penelitian ini, seperti jurnal ilmiah, buku terbitan, dan lain sebagainya.

Metode pengumpulan data yang digunakan adalah wawancara, observasi lapangan, dan dokumentasi.Analisis data dalam penelitian ini menggunakan model Milesdan Huberman, yaitu: reduksi data, penyajian data danpenarikan kesimpulan (Ahmadi, 2014). Dalam penelitian kuantitatif, instrumen penelitian harus diuji untuk mendapatkan data yang valid dan reliabel hal ini berbeda dengan penelitian kualitatif dimana yang diuji adalah datanya, dalam pengujian ini mengacu pada 4 kriteria yaitu derajat kepercayaan (credibility), keteralihan (tranferability), kebergantungan (dependability), dan kepastian (confirmability) Dari empat kriteria tersebut, pendekatan kualitatif memiliki delapan teknik pemeriksaan data, yaitu perpanjangan keikut-sertaan, ketekunan pengamatan, triangulasi, pengecekan sejawat (Hadi, 2016). Untuk memeriksa akurasi hasil penelitian ini yang digunakan yaitu mentriangulasi (triangulate) yang bertujuan untuk membangun justifikasi tema-tema secara koheren, kemudian yang kedua dalam memeriksa akurasi hasil penelitian dengan menerapkan member checking yang bertujuan agar informan yang yang memberikan data dapat mengetahui hasil penelitian dan memberikan komentar-komentar yang belum disampaikan atau meluruskan komentar yang salah (Creswell, 2016). 


\section{HASIL}

\section{Sosialisasi Gerakan Literasi Sekolah dan pendukung sarana dan prasarana}

Dalam mensukseskan Gerakan Literasi Sekolah (GLS) pihak sekolah sudah merencanakan kegiatan membaca setiap minggu sekali yaitu pada hari Jumat pukul 14.00 WIB dimana siswa diminta oleh wali kelasnya untuk membawa buku bacaan yang digemari sesuai aturan yang berlaku namun kegiatan ini masih tidak konsisten karena sekolah beranggapan bahwa kegiatan ini akan memakan waktu jadwal pelajaran pada hari jumat seperti yang diungkapkan oleh salah satu guru "sebenarnya kita sudah punya program yaitu anak-anak untuk. membaca 2 jam pembelajaran di hari jumat namun program jalan ditempat alias tidak konsisten karena memakan jam pembelajaran mapel lain".

Program Gerakan Literasi Sekolah nampaknya belum tersosialisasikan dengan baik di lingkungan SMP IT Insan Harapan, seperti yang diungkapkan oleh guru PAI mengatakan bahwa "saya belum merasakan sosialisasi gerakan literasi di lembaga ini namun saya hanya mengetabui lewat edaran kemendikbud bahwa program ini terkait dengan siswa membaca 15 menit sebelum Kegiatan Belajar Mengajar (KBM) berlangsung, untuk pengembangan-pengembangan gerakan ini saya hanya merasakan program 2 jam pembelajaran membaca disetiap mingguny selebihny a belum dikembangkan" dari wawancara ini menandakan bahwa pemahaman guru terkait dengan Gerakan ini adalah hanya sebatas membaca 15 menit sebelum kegiatan belajar mengajar dimulai namun esensi dari program ini diberlakukan guru tidak memahaminya, hal ini mengindikasikan peran sosialisasi yang kurang oleh pihak terkait sehingga sekolah masih kebingungan dalam mengimplementasikan kegiatan ini, padahal Gerakan ini diwujudkan untuk meningkatkan budi pekerti peserta didik sesuai permendikbud nomor 23 tahun 2015 yang bertujuan untuk meningkatkan karakter siswa.

Program GLS juga akan berjalan dengan sukses jika sarana dan prasarana lebih mendukung seperti fasilitas perpustakaan yang sesuai dengan kriteria sesuai dengan buku panduan dari Kementrian Pendidikan dan Kebudayaan seperti keberagaman sumber buku bacaan dan bahan bacaan literasi dalam bentuk digital ini sebagai kunci awal kesuksesan program Gerakan Literasi (GLS) dijalankan (Kemendikbud, 2017). Seperti yang diungkapkan petugas Pustakawan sekolah "disini banyakan buku paket pelajaran sekolah seperti buku IPS, IPA, PKN, PAI sedangkan untuk bukubuku yang menarik minat baca siswa masib kurang padahal anak-anak suka dengan buku seperti novel ensiklopedia namun jumlahnya terbatas dan tahun terbitnya sudab lama”.

Dari data input yang diperoleh ini akan mempengaruhi pelaksanaan implementasi program Gerakan Literasi Sekolah (GLS) di lapangan yang terlihat dari kegiatan awal sebelum program ini dijalankan, ini mengindikasikan bahwa input (masukan) dalam menjalankan sebuah program masih banyak kendala yang perlu diperbaiki, rekomendasi dari tahap input ini bahwa dinas terkait dan sekolah perlu memperbaikinya guna mensukseskan program Gerakan Literasi Sekolah (GLS). 


\section{Implementasi Gerakan Literasi Sekolah di SMP IT Insan Harapan}

Untuk melihat pelaksanaan kegiatan program Gerakan Literasi Sekolah (GLS) penulis melihat beberapa aspek sesuai dengan buku panduan dari kemendibud terbitan tahun 2017 dimana dilihat dari aspek penambahan buku bacaan siswa, perluasan terhadap sumber belajar siswa, dan peningkatan pelibatan publik.

1. Penambahan buku bacaan siswa

Keberhasilan dari program GLS ini adalah peningkatan jumlah dan ragam sumber buku bacaan, menurut panduan dari Kemendikbud bahwa GLS akan berhasil jika menerapkan strategi yaitu peningkatan sumber buku bacaan diantaranya yaitu:

a. Penyediaan bahan bacaan nonpelajaran yang beragam;

b. Penyediaan alat peraga dan mainan edukatif yang mendukung kegiatan literasi;

c. Penyediaan bahan belajar literasi dalam bentuk digital; dan

d. Program menulis buku bagi siswa, guru, dan tenaga kependidikan.

(Kementerian Pendidikan dan Kebudayaan, 2017)

Berdasarkan data temuan, sekolah hanya memperbanyak buku-buku bacaan dan masih bersifat buku bacaan yang kurang menarik siswa seperti buku paket pelajaran sehingga siswa kurang tertarik dengan buku-buku yang disediakan oleh sekolah. Namun tidak dipungkiri bahwa penambahan buku-buku baru yang dilakukan oleh pihak sekolah menambah minat bacaan siswa, ini seperti data yang diperoleh sebelum adanya penambahan buku baru rata-rata siswa membaca sehari di perpustakaan sebesar $20 \%$ dari total siswa sedangkan ketika sekolah menambahkan bukubuku baru jumlah pengunjung menjadi 30\% dari jumlah seluruh siswa di sekolah penambahan persentase ini juga akibat dari penerapan program membaca setiap hari jumat tersebut, siswa yang tidak memiliki buku bacaan yang menarik dirumah akan meminjam di perpustakaan.

Selain itu juga bahwa mainan yang bersifat edukatif masih kurang sekali di perhatikan di Sekolah meskipun sekolah menyediakan permainan ini seperti Congklak dan Egrang (permainan yang terbuat dari bambu) namun permainan ini digunakan tidak konsisten, hasilnya adalah anakanak menggunakan permainan ini diawal pembelian namun selebihnya siswa tidak minat untuk menggunakan permainan ini, selain itu juga bahwa perawatan permainan ini masih sangat minim hal ini berdasarkan temuan bahwa banyak alat peraga atau permainan edukatif yang rusak dan tidak terawat.

Bahan ajar literasi digital juga sebagai strategi dalam mensukseskan program GLS sudah dikembangkan disekolah ini, berdasarkan temuan dilapangan bahwa sekolah sudah menyediakan sarana dan prasarana berupa laboratoriaum komputer, dengan fasilitas ini siswa dapat mengakses informasi di laboratorium namun yang masih terkendala adalah konten-konten yang dibuat sekolah 
terutama karya-karya guru sifatnya masih terbatas, siswa memperoleh konten-konten bahan bacaan dari informasi luar sekolah, karya-karya guru yang diciptakan adalah hanya sebatas power point dan kuis-kuis yang dibuat dan kemudian di publish ke dalam website sekolah atau platform lain seperti google classroom dan quiriz:

Kegiatan menulis siswa juga sebenarnya sudah dikembangkan seperti kewajiban anak-anak kelas 9, dalam menyusun karya tulis sebagai syarat untuk memenuhi tugas mata pelajaran Bahasa Indonesia, namun program ini belum dipadukan dengan program Gerakan Literasi Sekolah (GLS) yang dikembangkan oleh sekolah.

2. Perluasan Akses terhadap Sumber Belajar dan Cakupan Peserta Belajar

Dalam strategi implementasi GLS juga Kemendikbud menyarankan perluasan akses terhadap sumber belajar dan cakupan peserta belajar diantaranya yaitu:

a. Pengembangan sarana penunjang yang membentuk ekosistem kaya literasi;

b. Penyediaan laboratorium yang berkaitan dengan literasi, misalnya, laboratorium bahasa, sains, finansial, dan digital;

c. Penyediaan pojok baca, baik di tiap kelas maupun di tempat-tempat strategis di sekolah;

d. Pengoptimalan perpustakaan sekolah;

e. Penyelenggaraan open house oleh sekolah yang sudah mengembangkan literasi;

f. Program pengimbasan sekolah; dan

g. Pelaksanaan kampanye literasi.

(Kementerian Pendidikan dan Kebudayaan, 2017)

Di SMP IT Insan Harapan dari strategi itu baru penyediaan laboratoriaun yang terbuka untuk akses siswa dan pengembangan program perpustakaan di setiap kelas dan pengembangan pojok baca di masing-masing kelas, namun lingkungan yang mendukung untuk pemberian informasi siswa seperti pamphlet yang berisi tulisan informasi di lingkungan sekolah belum di kembangkan, masih banyaknya dinding yang kosong ini perlu dikembangkan guna untuk menambah pengetahuan siswa yang membacanya.

Kampanye yang dilakukan oleh sekolah juga tidak dilakukan, hal ini seperti yang diungkapkan oleh beberapa siswa bahwa mereka tidak mengetahui program GLS ini siswa hanya sebatas mengetahui bahwa terdapat program yang setiap hari jumat yaitu membaca selama 2 jam pembelajaran.

3. Peningkatan Pelibatan Publik

Peningkatan pelibatan publik juga dapat dilakukan guna mendukung program GLS kegiatan publik ini meliputi: 
a. Pelaksanaan sesi diskusi dengan tokoh atau pegiat berbagai bidang literasi mengenai pengalaman dan pengetahuan mereka terkait dengan bidang yang mereka kuasai;

b. Pelaksanaan festival atau bulan literasi yang melibatkan pakar, pegiat literasi, dan masyarakat umum; dan

c. Pelibatan BUMN dan DUDI dalam pengadaan bahan bacaan dan kegiatan literasi di sekolah.

(Kementerian Pendidikan dan Kebudayaan, 2017)

Dalam pelibatan publik sekolah dalam membuat acara seringkali melibatkan masyarakat luar seperti kegiatan simfoni 1000 angklung yang diikuti oleh masyarakat luar, kemudian IIF (Islamic Inovation Festival), namun upaya pelibatan siswa dalam keikutsertaan masih sangat terbatas hal ini kegiatan masih didominasi oleh guru dalam mensukseskan kegiatan serta program-program literasi tidak dimasukan kedalam konsep acara hal ini seperti yang diungkapkan oleh guru IPA "sering kita mengadakan kegiatan yang melibatkan pibak. luar seperti IIF dan simfoni angklung namun kita sebagai guru yang mengurusinya dan dalam acara tersebut kita lupa memasukan program-program yang dicanangkan pemerintah seperti GLS tersebut".

\section{DISKUSI}

National Education Association (n.d.) telah mengidentifikasi keterampilan abad ke-21 sebagai keterampilan "The 4Cs." "The 4Cs" meliputi berpikir kritis, kreativitas, komunikasi, dan kolaborasi (Redhana, 2019). keterampilan ini bertujuan untuk meningkatkan sumber daya manusia yang mampu berdaya saing secara global. Upaya pemerintah dalam meningkatkan sumber daya manusia agar dapat bersaing di era globalisasi dengan cara meningkatkan kemampuan literasi masyarakatnya, sehingga masyarakat diharapakan akan meningkatkan kemampuan berpikir,dalam pembentukan karakter siswa dapat diperoleh dari kegiatan literasi, dimana siswa akan memperoleh informasi yang nantinya akan menjadi sebuah tindakan atau perilaku siswa yang terinternalisasikan dan menjadi pribadi yang baik yang diperoleh dari sumber buku bacaan.

Indonesia sebagai negara yang majemuk karena memiliki keberagaman kebudayaan, siswa diharapkan akan mendapatkan ilmu pengetahuan seperti pengetahuan budaya, melalui ini literasi nilai-nilai karakter seperti toleransi akan tercapai dengan baik, toleransi sangat dibutuhkan dalam pembelajaran abad 21 karena akan menciptakan kolaborasi pembelajaran yang harmonis sehingga kemampuan akan pemecahan fenomena-fenomena yang terjadi di masyarakat akan didiskusikan dengan baik (Laal, Laal, \& Kermanshahi, 2012).

Sesuai dengan tujuan dari gerakan literasi yaitu penumbuhan budi pekerti dan pembelajaran sepanjang hayat (Sunarso, 2016), harus ada sasaran utama dalam mengimplementasikan program, 
pemerintah membuat kebijakan program dengan konsep Gerakan Literasi Sekolah namun program ini perlu diperbaiki guna mensukseskan perubahan budi pekerti masyarakat dan pembelejaran sepanjang hayat, yang diperlu diperbaiki dari hasil temuan kasus dilapangan diantaranya:

1. Program perlu disosialisasikan dengan baik terutama terkait dengan Gerakan Literasi Sekolah harus melibatkan kepala komite, kepala sekolah, guru, dan siswa

2. Perlu adanya Pembina yang bertugas untuk mengarahkan agar program berjalan dengan baik sehingga sekolah tidak kebingungan dalam mengimplementasikan programnya

3. Perlu adanya dukungan terkait dengan sarana dan prasarana dalam mendukung kegiatan Gerakan Literasi Sekolah dalam rangka meningkatkan minat baca siswa, ini diperkuat dengan penelitian Sunarso \& Dodik bahwa perbaikan sarana dan prasarana akan meningkatkan minat baca siswa (Sunarso, 2016).

4. Sekolah harus serius dan konsisten dalam menerapakan Gerakan literasi sekolah seperti kegiatan membaca 15 menit sebelum belajar sehingga program tidak berhenti ditempat, kegiatan membaca selama 15 menit ini sesuai dengan peraturan Kementerian Pendidikan dan Kebudayaan Nomor 23 tahun 2015, sehingga tahap pembiasaan dalam program ini tercapai, tahap ini meliputi kegiatan rutin setiap hari membaca selama 15 menit dengan didukung fasilitas buku bacaan yang diminati siswa (Nuryana, Suroyo, Nurcahyati, Setiawan, \& Rahman, 2020).

5. Dalam pembuatan program disekolah seharusnya memperhatikan konsep Gerakan literasi sekolah dan memasukan 6 dasar aspek literasi, sehingga siswa dapat tumbuh minat bacanya

6. Sekolah perlu mengembangkan bahan bacaan digital sehingga dapat menarik minat baca siswa

Dalam penelitian-penelitian lain Gerakan Literasi Sekolah dalam iplementasinya masih banyaknya kendala seperti banyaknya sekolah yang masih inkosisten dalam melaksanakan kegiatan membaca 15 menit, kurangnya sumber buku bacaan di perpustakaan, serta rendahnya keterlibatan guru yang seharusnya menjadi contoh dalam mensukseskan Gerakan Literasi Sekolah yang masih kurang disadari (Nuryana et al., 2020). Rendahnya faktor pendukung lingkungan fisik serta guru sebagai role model dalam mendukung kegiatan literasi ini juga banyak ditemui di beberapa sekolah di Pekanbaru Riau (Suryawati, Suzanti, Suwondo, \& Yustina, 2018).

Dalam pengembangan kegiatan-kegiatan sekolah yang mengundang masyarakat diluar komponen sekolah harusnya mempermudah dalam pengembangan aspek dasar literasi, seperti mengasah kemampuan finansial serta kemampuan memahami budaya dan kenegaraan. 2 aspek dasar literasi tersebut dapat terinternalisasikan ke siswa sebagai pembentukan karakter seperti peningkatan jiwa kewirausahaan siswa dan sikap toleransi sesama penjual dan pembeli. Dalam penelitian Zulkarnain \& Akbar mengatakan bahwa kegiatan bazaar juga dapat mengembangkan soft skill seperti keterampilan berwirausaha, kreatif, berani, bertanggung jawab (Zulkarnain \& Akbar, 
2018). Selain pengembangan bazaar sebagai wujud pendukung program gerakan literasi, perlu diperhatikan aspek pengembangan dasar literasi kebudayaan dan kenegaraan karena ini penting untuk meningkatkan karakter siswa seperti solusi disinformasi pada generasi millennial di Indonesia (Pratiwi \& Asyarotin, 2019), disinformasi yang terjadi pada generasi millennial ini menghindari kemunculan hoax dan hate speeech yang beredar di masyarakat, generasi millenial harus berkembang nilai budaya dan kewargaan dalam gaya hidup melalui pembelajaran-pembelajaran yang berarti disekolah dengan pengembangan-pengambangan programnya sehingga program gerakan literasi sekolah dapat diimplementasikan dengan sukses.

Pengembangan literasi digital juga perlu ditingkatkan di masing-masing sekolah. Literasi digital ini berfungsi sebagai media transfer pengetahuan dan keterampilan menggunakan media digital atau alat komunikasi, pengembangkan ini bertujuan agar menumbuhkan komunikasi dan kemampuan interaksi dalam kehidupan sehari-hari (Nuryana et al., 2020). Pengembangan literasi digital ini sebagai sarana untuk mendukung pembelajaran kontekstual dimana banyak informasi kehidupan yang disajikan sehingga akan menumbuhkan minat belajar, pembeleajaran ini sebagai konsep dasar yang membantu guru mengaitkan antara materi yang diajarkan dengan situasi dunia nyata siswa itu sendiri dan mendorong peserta didik membuat hubungan antara pengetahuan yang dimilikinya dengan penerapan dalam kehidupan mereka sehari-hari (Syaiful Sagala, 2008).

\section{PENUTUP}

Dari hasil temuan penelitian ini bahwa masih banyaknya yang perlu diperbaiki mulai dari masukan awal (input) seperti perencanaan program dengan matang, sarana dan prasarana, dan sosialisasi program. Sedangkan untuk proses kegiatanya perlu adanya konsistensi kegiatan seperti membaca 15 menit sebelum pembelajaran dimulai dan konsistensi dalam menjalankan program yang sudah dibuat dan direncanakan diawal seperti membaca 2 jam pembelajaran di tiap minggunya, memasukan pengembangan 6 literasi dasar yaitu baca tulis, numerasi, sains, finansial, digital, serta budaya dan kewargaan disetiap kegiatan-kegiatan sekolah. Dari perbaikan-perbaikan ini diharapkan akan menghasilkan keluaran (output) yang sesuai dengan aspek-aspek dari pengembangan pendidikan karakter sesuai dengan permendikbud nomor 23 tahun 2015. Dalam implementasi GLS di sekolah SMP IT Insan Harapan masih dalam tahap pembiasaan karena program dijalankan belum secara teratur atau konsisten sehingga sulit bagi peneliti untuk melihat hasil keluaran akibat dari program tersebut. 


\section{REFERENSI}

Abbas, K., \& Bin Hassan, Z. (2014). Integrated Learning Model Cultural-Art and Character Education. International Journal for Innovation Education and Research, 2(8), 2-8.

Antasari, I. W. (2017). Implementasi Gerakan Literasi Sekolah Tahap Pembiasaan di MI Muhammadiyah Gandatapa Sumbang Banyumas Indah. Acta Universitatis Agriculturae et Silviculturae Mendelianae Brunensis, 16(1), 24-25. https://doi.org/10.30798/makuiibf.323102

Creswell, J. W. (2016). Research Design: Pendekatan Metode Kualitatif, Kuantitatif, dan Campuran. In $S A G E$ Publication.

Hadi, S. (2016). Pemeriksaan Keabsahan Data Penelitian Kualitatif Pada Skripsi. Jurnal Ilmu Pendidikan Universitas Negeri Malang, 22(1), 109874.

Irkhamiyati, I. (2017). Evaluasi Persiapan Perpustakaan Stikes 'Aisyiyah Yogyakarta Dalam Membangun Perpustakaan Digital. Berkala Ilmu Perpustakaan Dan Informasi, 13(1), 37. https://doi.org/10.22146/bip.26086

Kemendikbud. (2017). Panduan Gerakan Literasi Nasional. Retrieved from https://gln.kemdikbud.go.id/glnsite/wp-content/uploads/2017/08/panduan-gln.pdf\%5C

Kementerian Pendidikan dan Kebudayaan. (2017). Panduan Gerakan Literasi Nasional.

Laal, M., Laal, M., \& Kermanshahi, Z. K. (2012). 21st Century Learning; Learning in Collaboration. Procedia - Social and Behavioral Sciences, 47, 1696-1701. https://doi.org/10.1016/j.sbspro.2012.06.885

Nuryana, Z., Suroyo, A., Nurcahyati, I., Setiawan, F., \& Rahman, A. (2020). Literation movement for leading schools: Best practice and leadership power. International Journal of Evaluation and Research in Education, 9(1), 227-233. https://doi.org/10.11591/ijere.v9i1.20279

Pratiwi, A., \& Asyarotin, E. N. K. (2019). Implementasi literasi budaya dan kewargaan sebagai solusi disinformasi pada generasi millennial di Indonesia. Jurnal Kajian Informasi \& Perpustakaan, 7(1). https://doi.org/10.24198/jkip.v7i1.20066

Redhana, I. W. (2019). Mengembangkan Keterampilan Abad Ke-21 Dalam Pembelajaran Kimia. Jurnal Inovasi Pendidikan Kimia, 13(1).

Sujadi, Eko. (2017). Penerapan Pendidikan Karakter Cerdas Format Kelompok Untuk Meningkatkan Nilai Kejujuran Mahasiswa Bimbingan Konseling Islam (BKI) Institut Agama Islam Negeri (IAIN) Kerinci. Tarbawi: Jurnal Ilmu Pendidikan, 13(1), 97-108.

Sunarso, D. K. (2016). Pengaruh Minat Baca, Waktu Belajar, Sarana Prasarana Dan Kemampuan Mengajar Guru Terhadap Hasil Belajar Pkn. SOCLA: Jurnal Ilmu-Ilmu Sosial, 13(2). https://doi.org/10.21831/socia.v13i2.12572

Suryawati, E., Suzanti, F., Suwondo, S., \& Yustina, Y. (2018). The implementation of schoolliteracy-movement: Integrating scientific literacy, characters, and HOTS in science learning. Jurnal Pendidikan Biologi Indonesia, 4(3). https://doi.org/10.22219/jpbi.v4i3.6876

Syaiful Sagala. (2008). Konsep dan Makna Pembelajaran Cetakan ke 6.

Tarmidzi, T., \& Astuti, W. (2020). Pengaruh Kegiatan Literasi Terhadap Minat Baca Siswa di Sekolah Dasar. Caruban: Jurnal Ilmiah Ilmu Pendidikan Dasar, 3(1), 40. https://doi.org/10.33603/caruban.v3i1.3361

Vanbela, V. T., Fuad, N., \& Marini, A. (2018). Indonesian Journal of Primary Education Evaluasi Program Gerakan Literasi Sekolah di SDN Rorotan 05 Kota Jakarta Utara. 2(2), 1-13.

Zulkarnain, Z., \& Akbar, E. (2018). Implementasi Market Day Dalam Mengembangkan Entrepreneurship Anak Usia Dini Di Tkit an-Najah Kabupaten Aceh Tengah. JPUD - Jurnal Pendidikan Usia Dini, 12(2), 391-400. https://doi.org/10.21009/jpud.122.20 